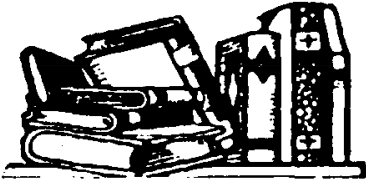 \\ EDITOR'S CORNER
}

The Harvard Business School and the Newcomen Society of the United States announce a postdoctoral fellowship in business history to support twelve months of residence and research at the Harvard Business School for the academic year 1995-96. The stipend is $\$ 44,000$.

The purpose of this award is to enable scholars who have received the Ph.D. in history, economics, or a related discipline within the past ten years to improve their professional acquaintance with business and economic history, to increase their skills as they relate to this field, and to engage in research that will benefit from the resources of the Harvard Business School and the Boston scholarly community. The successful applicant will participate in the school's business history course, seminar, and case development activities. Those interested should request an application from Professor Thomas K. McCraw, Morgan 297, Harvard Business School, Boston, MA 02163. Completed applications for the 1995-96 Newcomen Fellowship must be received no later than 1 November 1994.

Harvard University announces the Alfred D. Chandler, Jr., Traveling Fellowships in Business History and Institutional Economic History. The grants will range from $\$ 1,000$ to $\$ 3,000$, with the funds awarded each year totaling approximately $\$ 15,000$. The purpose of the fellowships is to facilitate library and archival research in business history or in institutional economic history, broadly defined. Topics such as labor relations and government regulation would also be considered for awards, if the approach is primarily institutional. The intent of the awards is to encourage the kind of research exemplified by the published work of Alfred D. Chandler, Jr.

Three categories of applicants will be eligible for grants:

- Harvard University graduate students in history, economics, business administration, or a related discipline such as sociology, government, or law, whose research requires travel to distant archives or repositories

- Graduate students or nontenured faculty in those fields from other North American universities, whose research requires travel to the Boston-Cambridge area (to study, for example, in the collections of the Baker, Widener, McKay, Law, Kress, or Houghton libraries)

- Harvard College undergraduates writing senior theses in these fields, whose research requires similar travel. 
The fellowships will be administered by a committee of three faculty members from Harvard's Business School and History and Economics departments. The deadline for receipt of applications is 1 December 1994, and recipients may use their awards at any time during calendar 1995.

Requests for applications should be sent to the committee chair, Professor Thomas K. McCraw, Morgan 297, Harvard Business School, Boston, MA 02163.

The Society for Historians of the Early American Republic (SHEAR) will hold its fourteenth annual meeting on 20-22 July 1995 at the University of Cincinnati. Proposals for individual papers or entire sessions (two papers per session) should be sent no later than 31 January 1995 to the program chair, Peter S. Onuf, Department of History, University of Virginia, Charlottesville, VA 22903 (telephone: 804-924-6383; fax: 804-924-7891). SHEAR welcomes scholarship from all disciplines bearing on the history and culture of the early American republic, and it extends a special invitation to younger scholars, public historians, and teachers. Proposals should include a brief (one-page) prospectus for each paper and a c.v. for all participants. Unless affiliated with disciplines other than history, panelists are required to be members of SHEAR.

The European Association for Banking History (EABH) will award a prize of 2,500 ecus to an individual scholar or a team consisting of a maximum of three scholars working on an institutional, economic, or social aspect of the history of European banking or on a biography of a European banker or banking dynasty. The studies should meet standard academic requirements, should be unpublished, and should be $80,000-120,000$ words. Applicants should not be over the age of thirty-five at the time manuscripts are submitted. Texts will be accepted in any European language, but each entry must be accompanied by a 3,000-word (ten-page) abstract in English. In addition to the cash prize, the EABH will commit itself to the publication of the winning manuscript. For the 1995 prize, manuscripts must be submitted by 31 December 1994 to Prof. Dr. Manfred Pohl, European Association for Banking History e.V., Alte Rothofstr. 2-4, 60313 Frankfurt, Germany (telephone: 69-131-0231; fax: 69-295074).

The James J. Hill Reference Library will award a number of grants of up to $\$ 2,000$ to support research in the James J. Hill and Louis W. Hill papers. The deadline for applications is 1 November 1994, and the awards will be announced early in 1995. For more information, please contact W. Thomas White, Curator, James J. Hill Reference Library, 80 West Fourth Street, St. Paul, MN 55102.

Papers are invited for a conference on the subject "Working-Class Lives/ Working-Class Studies," an interdisciplinary exploration of working-class life and culture in America by both academic and non-academic workers to be held at Youngstown State University on 9-11 June 1995. The conference 


\section{Editor's Corner / 146}

organizers seek papers, artwork, fiction, poetry, and other representations of American working-class life and culture for both formal and informal presentations, discussion, and performance. Possible areas of exploration include literature about and by the working class, social history, material culture, journalism, art, ethnography, biography, and autobiography or personal narratives. Each presenter should send an abstract of 250-500 words describing his or her project and suggestions for the format in which it might best be presented; proposals for panel sessions are also welcome. Address correspondence to Bill Mullen or Linda Strom, Department of English, or Janet Ore, Department of History, Youngstown State University, Youngstown, OH 44555-0001. The deadline for proposals is 15 January 1995. The organizers can also be reached by e-mail at linkon@unixl.cc.ysu.edu or by telephone at $216-742-3415$. 